УДК 330.341.1:679.8

\title{
ТЕОРЕТИЧНІ АСПЕКТИ ФОРМУВАННЯ СТРАТЕГІЯ ІННОВАЦІЙНОГО РОЗВИТКУ ПІДПРИЕМСТВ КАМЕНЕОБРОБНОЇ ГАЛУЗІ
}

\author{
Толстова А.В., к.е.н., доцент, \\ Кок Д.Б., магістр ІППК (УкрДУЗТ)
}

\begin{abstract}
В статті досліджено стан та проблеми підприємств каменеобробної галузі, визначено основні етапи формування та реалізаиії інноваційного розвитку. Визначено щзо основним шляхом подальшого розвитку зазначених підприємств $\epsilon$ їх перехід на інноваиійний шлях розвитку. Досягнення стратегічної мети - переходу на високотехнологічне виробництво якісної продукиії, пропонується за рахунок інтеграції підприємств каменедобування, каменеобробки, підприємств машинобудування та інновачійного сектору (профільні наукові установи), створення спеціалізованих, розтамованих біля кар'єрів підприємств, впровадження комп'ютерно-інтегрованої виробничої системи, переходу на інноваційно-інвестиційну модель фінансового забезпечення інноваційного розвитку.
\end{abstract}

Ключові слова: інноваційний розвиток, стратегія підприємства, підприємства каменеобробної галузі, технічне переозброєння, технологічна лінія.

\section{ТЕОРЕТИЧЕСКИЕ АСПЕКТЫ ФОРМИРОВАНИЯ СТРАТЕГИИ ИННОВАЦИОННОГО РАЗВИТИЯ ПРЕДПРИЯТИЙ КАМНЕОБРАБАТЫВАЮЩЕЙ ОТРАСЛИ}

\author{
Толстова А.В., к.э.н., доцент, \\ Кок Д.Б., магистр ИППК (УкрГУЖТ)
}

В статье исследовано состояние и проблемы предприятий камнеобрабатывающей отрасли, определены основные этапы формирования и реализаџии инновационного развития. Определено, что основным путем дальнейшего развития указанных предприятий является переход на инновачионный путь развития. Достижение стратегической цели - перехода на высокотехнологичное производство качественной продукции, предлагается за счет интеграции предприятий камнедобывающей, обрабатывающей отрасли, предприятий машиностроения и инновачионного сектора (профильные научные учреждения), создания специализированных, расположенных у карьеров предприятий, внедрения компьютерноинтегрированной производственной системы, перехода на инновачионно-инвестиционную модель финансового обеспечения инновачионного развития.

Ключевые слова: инновационное развитие, стратегия предприятия, предприятия камнеобрабатывающей отрасли, техническое перевооружение, технологическая линия.

\section{THEORETICAL ASPECTS OF THE STRATEGY OF INNOVATIVE DEVELOPMENT OF ENTERPRISES STONE PROCESSING INDUSTRY}

\author{
Tolstov A.V., Candidate of Economic Sciences, associate professor, \\ Kok D. B., Master IPPK (USU of RT)
}

In the article the state and problems of the stone processing industry of enterprises, the basic stages of formation and implementation of innovative development. It was determined that the main way of the further development of these enterprises is a transition to an innovative path of development. Achieving the strategic objective - the transition to high-tech production of quality products offered by

(C) Тостова A.B.,

Кок Д.Б.
Вісник економіки транспорту і промисловості № 52, 2015 
the integration of enterprises stone mining, processing industry enterprises of mechanical engineering and innovation sector (specialized research institutions), the creation of specialized, located at the quarry companies, the introduction of computer-integrated manufacturing system, the transition to innovation -Investment model of financial support innovative development.

Keywords: innovative development strategy of enterprises, stone processing industry, modernization, technological line.

Постановка проблеми. Сьогодні світове суспільство стикається з інноваційними викликами, пов'язаними 3 розвитком високих технологій, інформатизацією, зміною змісту праці та якості робочої сили. Інтенсивний розвиток передбачає наявність якоїсь основи, яка зумовлюе умови, що сприяють кардинальному прискоренню інноваційних процесів.

Досягнення конкурентних переваг на ринку можливо при реалізації правильно обраної стратегії, яка втілює бачення підприємства, i дозволяє максимально використовувати його потенціал. Найбільш перспективним з позицій інтенсивного розвитку підприємства $\epsilon$ інноваційний розвиток. Саме реалізація стратегії інноваційного розвитку дозволяє домогтися значної переваги на ринку, посилити і надовго закріпити свої конкурентні позиції.

Аналіз останніх досліджень та виділення невирішених частин загальної проблеми. Питанням інноваційного розвитку національних підприємств, формування стратегії розвитку, розвитку каменедобувної галузі присвячено багато робіт вчених, серед яких: С.А. Агарков, Е.С. Кузнєцова, М.О.Грязнова, Н.М. Богацька, О. Дембіцька, К. О. Бояринова, Р. Ф. Гаріфуллін, В.Л. Дикань, В.О. Зубенко, О.В. Маковоз, І.В. Токмакова, О.В. Шраменко, В.В. Македон, Д.С. Рубець, А.П. Наливайко, О.В. Нікуліна, Ю.А. Павлов, А.Н. Петрова, А. Б. Трофімчук, .М. Шульгіна, В.В. Юхименко [1-13]. Однак, в умовах поглиблення кризових явищ залишається відкритим питання переходу на інноваційний розвиток підприємств каменеобробної галузі, формування стратегії їx інноваційного розвитку.

Метою статті $\epsilon$ дослідження стану підприємств каменеобробної галузі, визначення основних етапів розробки та реалізації стратегії інноваційного розвитку підприємств, формування основних положень стратегії.

Виклад основного матеріалу. Україна $\epsilon$ однією 3 найбагатших у світі країн, яка має значні запаси природних ресурсів. Вона має найбільші в світі запаси декоративнооблицювального каменю, в основному гранітів. Український кристалічний щит простягається від Волині до берегів Азовського моря шириною 150-200 кілометрів. Розвідані запаси блочного каменю становлять близько 200 млн.м³. Щорічно добуваючи і переробляючи в середньому близько мільйона тонн граніту (в одному кубічному метрі - близько 3 тонн), світова промисловість тільки українського граніту могла б працювати 600 років. За підрахунками американських фахівців, в Україні знаходиться запасів декоративнооблицювального каменю вартістю близько 20 трильйонів доларів [14].

Нині в Україні нараховується близько трьохсот родовищ та проявів декоративного каменю, $з$ яких розроблюється майже півтори сотні, загальний річний видобуток блоків на яких становить 150-160 тис. м². В Україні працює близько 800 каменеобробних підприємств різної потужності та різних форм власності, які щорічно випускають приблизно 2,5 млн. м² продукції з декоративного каменю. Маючи близько $4 \%$ світових запасів декоративного каменю, Україна виготовляє лише $0,5 \%$ кам'яної продукції від світового рівня. Імпорт кам'яної продукції в Україну значно перевищує іï експорт [15]. Так в 2013 р. спостерігається зростання обсягів імпорту будівельного каменю. Обсяг імпорту за вісім місяців 2013 року склав 21,4 млн. дол., що на $33 \%$ більше обсягів аналогічного періоду попереднього року [16]. В Україну завозиться мармур, граніт, сланець, вапняк, травертин та інші види каменю (базальт, лабрадорит, габро та ін.). Частка мармуру в структурі імпорту 2013 склала 73\%, що на 7 \% більше ніж у попередньому році. Частка граніту, навпаки, зменшилася на 7 \% і склала $15 \%$ від загального обсягу імпортованого каменю [15].

$$
\text { Сьогодні каменедобувна i }
$$

каменеобробна галузі $є$ важливими складовими індустріального потенціалу країни. Але в Україні з розвіданих 110 родовищ граніту - 
розробляється трохи більше 40 [14]. Лідируючи в світі за запасами декоративнооблицювального каменю, Україна посідає одне 3 останніх місць 3 його видобування, а вітчизняна каменеобробна галузь за своїми темпами розвитку випереджає темпи зростання каменедобувної та відповідно відчуває значний дефіцит у блоках каменю.

Основними причинами таких тенденцій розвитку каменедобувної i каменеобробної галузі, їх підприємств є відсутність передових технологій та обладнання; недостатня вивченість структур покладів декоративного каменю; відсутність ефективних методик геометризації покладів декоративного каменю для формування раціональних технологічних комплексів видобування блоків; недостатні обгрунтування технологічних рішень i параметрів та їх неузгодженість 3 структурами покладів. Класичні ж методи не дають можливість одержати необхідну інформацію про якісні характеристики масиву [15].

Слід зазначити, що використання старих «вибухових» технологій добування не лише руйнують структуру каменю, але i приводять до його великих втрат. Сьогодні передові підприємства, виробництво яких базується на сучасному імпортному технологічному обладнанні 3 видобутку й обробки каменю, обробку відділення моноліту від масиву проводить шляхом нарізки щілин канатом, армованим алмазними кільцями, 3 подальшим зрушенням спеціальними подушками. При цьому виробництво в 2-3 рази вище, ніж за традиційною технологією. Впровадження технологічних ліній для виробництва тонких плит збільшуе продуктивність праці на 20-30\% i дозволяє раціональніше використовувати сировину.

Висока ж конкуренція на сучасному світовому ринку природного каменю диктує необхідність зниження собівартості видобутих блоків каменю та підвищення їх якості. Цього можна досягти, перш за все, за рахунок всебічного вивчення структурних i декоративних особливостей масиву природного каменю та його геометризації шляхом використання інформаційно-комп'ютерних технологій та впровадження на цій основі ефективних технологій каменедобування, каменеобробки 3 використанням високотехнологічного обладнання.
Каменеобробна галузь України містка й неструктурована. Вона здебільшого представлена малими підприємствами, що не відчувають конкуренції ні за ресурси, ні за ринки збуту. Але зростання вимог до продукції постійно, як на вітчизняному, так і на світовому ринку, зростання конкуренції, вимагає від каменеобробних підприємств проведення переобладнання та автоматизації.

Забезпечення розвитку підприємств каменеобробної та каменедобувної галузей потребує підтримки держави в аспекті структурного удосконалення галузей, удосконалення системи тендерів та аукціонів щодо проведення каменедобувних та каменеобробних робіт.

Сучасні технології та обладнання вимагають чималих витрат. Кожен кубічний метр потужностей 3 видобутку обходиться в 200 - 500 доларів капіталовкладень. Крім того, потрібно створити інфраструктуру, інженерне забезпечення, переробку відходів виробництва.

В умовах загострення конкуренції, підвищення вимог щодо якості продукції потребує від підприємств каменеобробної та каменедобувної промисловості перехід на інноваційний шлях розвитку. Інноваційний розвиток слід розглядати як цілеспрямований безперервний процес здійснення інновацій в науковій, виробничій, економічній, комерційній, фінансовій, маркетинговій, управлінській діяльності підприємства, спрямованій на максимально повне задоволення суспільних потреб на основі реалізації наукових досягнень у процесі виробництва для отримання максимального економічного, соціального та екологічного ефекту, вираженого в зміні економічних показників. Управління інноваційним розвитком підприємства повинно здійснюватися на основі методів i засобів впливу на інноваційні процеси, заснованих на формуванні інноваційного потенціалу та його перетворенні на інноваційний капітал в умовах розвитку інтеграційних процесів взаємодії підприємств каменедобувної та каменеобробної галузі [9]. Основним інструментом інноваційного розвитку підприємства $є$ його стратегія.

Інноваційна стратегія розвитку підприємства - це комплекс цілей і установок, правил прийняття рішень і способів перекладу підприємства (фірми) зі старого (існуючого) 
положення в новий (цільовий) стан на основі впровадження інновацій - технологічних, продуктових, організаційних, управлінських, економічних, соціальних - i позиціонування підприємства на конкурентних ринках товарів і послуг $[17,18]$. Тобто інноваційна стратегія завжди виражається у визначенні типу цільової поведінки підприємства на конкурентних ринках.

Основу вироблення інноваційної стратегії становлять цілі підприємства, масштаб і характер діяльності, життєвий цикл інновації, рівень інноваційного розвитку організації i науково-технічна політика.

При розробці інноваційної стратегії необхідно вирішити наступні основні завдання:
- визначити тип інноваційної політики, найбільш відповідний цілям і ринковій позиції підприємства;

- забезпечити відповідність інноваційної стратегії організаційній структурі, інфраструктурі та системі управління інформацією на підприємстві;

- визначити критерії успіху на можливо більш ранніх стадіях розробки інноваційного проекту;

- вибрати оптимальну процедуру моніторингу та контролю за ходом реалізації інноваційного проекту.

Формування та реалізація стратегії інноваційного розвитку передбачає послідовну реалізацію певних етапів (рис. 1).

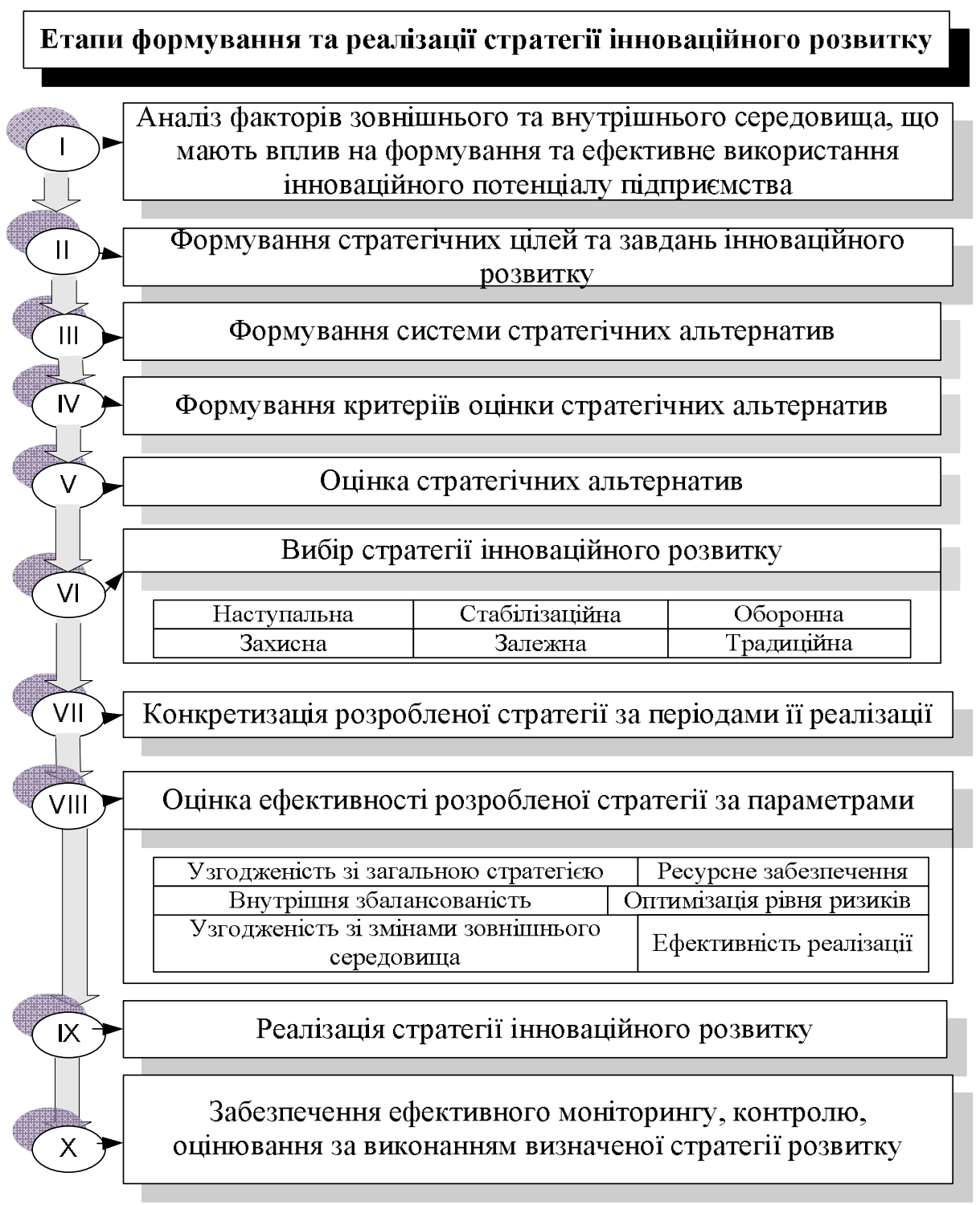

Рис. 1. Процес формування стратегії підприсмства 
На першому етапі проводиться аналіз внутрішнього та зовнішнього середовища підприємства, визначається рівень інноваційного потенціалу підприємства, сильні, слабкі сторони, можливості та загрози розвитку. На цьому етапі передбачається збір інформації, визначення об’єктів дослідження, параметрів, показників та критеріїв дослідження можливостей розвитку підприємства, його потенціал $[6,8,11]$.

Одними 3 ключових етапів формування стратегії є визначення стратегічних цілей та завдань стратегічного управління, які відповідатимуть визначеним можливостям інноваційного розвитку підприємства. Далі на основі визначених цілей та можливостей розвитку формується система стратегічних альтернатив, які сприятимуть досягненню поставлених цілей. Після того як визначені цілі, основні завдання стратегії, запропоновані стратегічні альтернативи слід переходити до етапу вибору стратегії підприємства. Визначення стратегії для підприємства принципово залежить від конкретної ситуації, у якій воно знаходиться $[8,11]$.

Після виконання аналітичної роботи, здійснення відповідних розрахунків, обговорення альтернативних варіантів розвитку подій приймається управлінське рішення щодо вибору стратегії, яку надалі деталізують за напрямами інноваційної політики й реалізують згідно 3 планом. Для полегшення реалізації стратегії доцільно проводити іiі деталізацію шляхом складання тактичних планів.

Якщо в процесі формування і реалізації стратегії виявлено певні відхилення фактичних значень показників від планових $\mathrm{i}$ від визначених умов інноваційної діяльності підприємства, то відбувається коригування стратегії на тому етапі, на якому виявлено дане відхилення.

Заключним етапом формування та реалізації стратегії інноваційного розвитку підприємства $€$ забезпечення ефективного моніторингу, контролю, оцінювання ефективності визначеної стратегії розвитку, який дозволяє вчасно внести корективи до стратегії, сформувати базу даних на майбутнє.

Проведене дослідження стану підприємств каменеобробної та каменедобувної галузі дозволяє стверджувати, що для забезпечення інноваційного розвитку доцільно впроваджувати захисну стратегію інноваційного розвитку, яка пов'язана 3 опануванням нової технології i завдяки ій виходом на нові ринки.

Стратегічною метою інноваційного розвитку підприємств каменеобробної галузі пропонуємо визначити: перехід на високотехнологічне виробництво якісної продукції. До основних завдань стратегії інноваційного розвитку слід віднести:

- безперервне зростання номенклатури, ускладнення конструкції, поліпшення дизайну і підвищення якості виробів, що випускаються (архітектурно-будівельних, художніх, ювелірних і т.д.);

- створення i впровадження нових ефективних виробничих технологій на базі високопродуктивного автоматизованого обладнання - автоматичних переналагоджуваних ліній, верстатів 3 числовим програмним управлінням, засобів автоматичного контролю і т. д .;

- широке використання комп'ютерних систем для автоматизованого проектування складних виробів, технологічної підготовки їх виробництва та управління технологічними та виробничими процесами;

- збільшення організаційної гнучкості виробництва при використанні нових інформаційних і комунікаційних технологій;

- інтеграція 3 каменедобувними підприємствами, 3 розробниками i постачальниками технологічного обладнання, оснащення та інструменту, а також з основними споживачами кам'яної продукції.

Важливим інструментом інноваційного розвитку підприємств каменеобробної галузі $€$ налагодження коопераційних зв'язків між підприємствами каменеобробки, каменедобування, підприємствами гірничого машинобудування, машинобудування, які спеціалізуються на виробництві технологічного обладнання, оснащення та профільних науково-виробничих установ. Інтеграція зазначених підприємств в інноваційно-промислові комплекси дозволить створити інноваційно-технологічне середовище для розвитку виробничого потенціалу підприємств, сформувати ефективну систему взаємовідносин самостійних підприємств, пов'язаних 3 інноваційним розвитком логістичного процесу і об'єднанням знань, які знаходяться в основі формування інноваційних потоків [5]. 
Об'єднання таких підприємств у єдину логістичну систему сприятиме раціоналізації системи управління матеріально-технічними потоками, мінімізації витрат, підвищенню інвестиційної привабливості підприємств, що, у свою чергу, дозволить модернізувати виробництво, створювати якісну продукцію, конкурентоспроможну на міжнародному ринку $[19,20]$.

Досвід провідних країн показує, що формування спеціалізованих, розташованих біля кар'єра підприємств дозволяє значно знизити собівартість виробництва [21]. Діяльність таких підприємств повинна бути направлена на роботу лише з одним матеріалом i виробляти тільки один тип нескладної продукції. За рахунок оптимізації всіх режимів розпилу, підбору найефективнішого інструменту, максимізації продуктивності праці, економії на сировину (дешева доставка, використання негабаритних, маленьких блоків, відвалу), ефективної утилізації відходів (наприклад, виготовлення маленької фігурної плитки) підприємству при кар'єрі вдасться досягти ще більш низької собівартості виробництва.

Наступним інструментом стратегії інноваційного розвитку підприємств каменеобробної галузі $\epsilon$ впровадження комп'ютерного управління та інформаційної підтримки виробничої системи, яка забезпечує всі стадії життєвого циклу виробів (ЖЦВ).

Комп'ютерно-інтегрована виробнича система (КВП або СІМ), побудована на основі концепції ЖЦВ, повинна вирішувати такі завдання: вивчення ринку і пошук сегментів для ефективного освоєння (маркетинг); формулювання технічних вимог, розробку концепції та проектування виробів; матеріально-технічне постачання виробництва; розробку технологічних процесів і підготовку виробництва; виготовлення деталей, складання або монтаж виробів; контроль, проведення випробувань i дослідження продукції, що випускається; експлуатацію виробів і технічне обслуговування; ремонт і реставрацію виробів; демонтаж і утилізацію відходів в кінці терміну служби виробів [10].

Створення єдиного інформаційного простору каменеобробного підприємства, а також можливість включення в це середовище співвиконавців, постачальників і замовників продукції повинно здійснюватися за допомогою комп'ютерних засобів управління даними про вироби (Product Data Management - PDM). Такі засоби є в інтегрованих комп'ютерних системах конструкторсько-технологічного проектування, підготовки та управління виробництвом різноманітних виробів (програмні комплекси типу CAE-CAD-CAM-PDM-ERP) [22].

Ключовими заходами стратегії інноваційного розвитку $\epsilon$ технічне перетворення підприємств, удосконалення технологій переробки, створення кам'яного бренду. Однак їх реалізація потребує залучення фінансових ресурсів, які на сьогодні $\epsilon$ дефіцитними. 3 метою інвестиційного забезпечення інноваційного розвитку підприємства пропонуємо перехід на інноваційно-інвестиційну модель фінансового забезпечення. В такій моделі інновації будуть об'єктом, який потребує інвестицій. В такому випадку зростає інвестиційна привабливість підприємства, проекту, а інвестор є третьою стороною у взаємовідносинах «замовник виробник». Саме тому до таких відносин слід залучати фінансові структури [3]. Перспективним $є$ залучення венчурних інвесторів.

Слід зазначити, курс на інноваційний розвиток підприємств каменеобробної галузі потребує підтримки держави. Основними стимулами для підприємств, які визначали своїм шляхом розвитку - інноваційний, з боку держави можуть виступати податкові знижки, пільгове оподаткування, пільгове кредитування, податкові канікули і т.п.

Висновок. В сучасних умовах розвитку підприємства каменеобробної галузі знаходяться в складному становищі. Вони потребують технічного переобладнання, удосконалення технологій переробки, створення бренду, оновлення технологічних ліній та ін. Основним шляхом подальшого розвитку зазначених підприємств $\epsilon$ їх перехід на інноваційний шлях розвитку. Стратегія інноваційного розвитку підприємства каменеобробної галузі повинна бути направлена на налагодження високотехнологічного виробництва якісної продукції. Цього можливо досягти за рахунок інтеграції підприємств каменедобування, каменеобробки, підприємств машинобудування та інноваційного сектору (профільні наукові установи), створення спеціалізованих, розташованих біля кар'єрів підприємств, 
впровадження комп'ютерно-інтегрованої виробничої системи, переходу на інноваційноінвестиційну модель фінансового забезпечення інноваційного розвитку.

\section{СПИСОК ЛІТЕРАТУРИ}

1. Агарков С.А. Инновационный менеджмент и государственная инновационная политика: монография [Электронный ресурс] / С.А. Агарков, Е.С.Кузнецова, М.О.Грязнова. Режим http://www.rae.ru/monographs/112

доступа:

2. Богацька Н.М., Дембіцька О. Аналіз інноваційної стратегії розвитку підприємств [Электронный ресурс] / Н.М. Богацька, О. Дембіцька. - Режим доступа: http://www.rusnauka.com/35_OINBG_2010/Econo mics/73899.doc.htm

3. Бояринова К. О. Інноваційний розвиток підприємств машинобудування на засадах нооуправління / К. О. Бояринова // Проблеми економіки. - 2014 . - № 2. - С.230235

4. Гарифуллин Р.Ф. Стратегии инновационного развития предприятия машиностроения / Р.Ф. Гарифуллин // Вопросы инновационной экономики. - 2011. - № 6 (6). C.27-34

\section{5. Дикань} восстановления

$$
\text { В.Л. }
$$

Механизм комплекса Украины в условиях логистической интеграции / В.Л. Дикань // // Вісник економіки транспорту і промисловості. - 2014. - №47. C.9-14

6. Дикань В.Л. Стратегічне управління: навч. посіб. / В. Л. Дикань, В.О. Зубенко, О.В. Маковоз, I.В. Токмакова, О.В. Шраменко - К.: «Центр учбової літератури», 2013. - 272 с

7. Македон В.В. Стратегічний інноваційний розвиток підприємств: теорія та методологія// В.В. Македон, Д.С. Рубець // Вісник НТУ «ХПІ». - 2013. - №45(1018). C. $75-86$

8. Наливайко А.П. Теорія стратегії підприємства. Сучасний стан та напрямки розвитку: монографія /А.П. Наливайко. - К.: KНEУ, 2001. - 227 c

9. Никулина О.В. Системный подход к управлению инновационным развитием промышленных предприятий [Электронный ресурс] / О.В. Никулина // Современные технологии управления, 2012. - №5 (17). Режим доступа к журн.: http://sovman.ru

10.Павлов Ю.А.Теория и практика автоматизированного проектирования объектов и процессов гибкого камнеобрабатывающего производства [Электронный ресурс] / Ю.А. Павлов. - Режим доступа: http://www.dissercat.com/content/teoriya-i-praktika -avtomatizirovannogo-proektirovaniya-obektov-iprotsessov-gibkogo-kamneobr\#ixzz3rZ8EJ1Eh

11.Стратегический менеджмент: учебник для вузов/ под ред. А.Н. Петрова. СПб.: Питер, 2005 - 496 с

12. Трофимчук А. Б. Розвиток рециклінгу у каменеобробних підприємствах [Електронний ресурс]. / А. Б. Трофимчук // Економіка. Управління. Інновації. - 2014. Випуск № 1 (11). - Режим доступу: irbisnbuv.gov.ua/.../cgiirbis_64.exe

13.Шульгіна, Л.М., Юхименко В.В. Інноваційний розвиток підприємств: формування стратегій: монографія / Л.М. Шульгіна, В.В. Юхименко; Нац. техн. ун-т України «КПІ». - К.: Univest PrePress, 2015. $212 \mathrm{c}$.

14.Добыча и обработка камня в Украине [Электронный ресурс]. - Режим доступа http://sdachi.net.ua/s.php?id=73

15.Криворучко А. О.. Обгрунтування методики геометризації габроїдних порід на основі визначення та оцінки показників структури та декоративності : Дис... канд. наук: 05.15 .01 - 2006.

16. Анализ украинского рынка керамической плитки, сантехники и натурального строительного камня в январеавгусте 2013 г. Отчет о результатах исследования для «Украинской ассоциации керамики». 2013. С.77

17. Інноваційний

менеджмент

[Електронний ресурс]. - Режим доступу: http://studme.com.ua/1609032213165/investirovani e/klassifikatsiya_innovatsionnyh_strategiy.htm

18. Інноваційний

менеджмент

[Електронний ресурс]. - Режим доступу: http://subject.com.ua/economic/innovative/12.html

19.Толстова А.В. Антикризова модель економічного розвитку сучасної України та іiі інвестиційне забезпечення / А.В. Толстова // Вісник економіки транспорту і промисловості. 2013. - №44. - С. 20-26

20. Толстова А.В. Кластерная экономика - современная парадигма 
экономического развития Украины / А.В. Толстова // The dominant of the humanism principle in modern social concepts and the civilized practice of public relations. - London.: Published by IASHE. -2015 . - p.27-30

21. Что хорошо украинцу и китайцу: как построить бизнес в Китае нашему человеку [Электронный pecypc] - Режим доступа http://www.companion.ua/articles/content?id=2694 77

22. Сычев Ю.И. Достижения и перспективы технологического прогресса в промышленности облицовочного камня. / И.Ю.Сычев // Горный журнал. - 2000. - №3. - С. 35

Рецензент д.е.н., професор УкрДУЗТ Кірдіна О.Г. Експерт редакційної колегії к.е.н., дочент УкрДУЗТ Полякова О.М.

УДК [330.322+330.341.1]:339.137.2

\title{
ІННОВАЦЙНО-ІНВЕСТИЦЙНН ПІДХОДИ ДО ЗАБЕЗПЕЧЕННЯ КОНКУРЕНТОСПРОМОЖНОСТІ УКРАЇНСЬКИХ ПІДПРИЕМСТВ НА ГЛОБАЛЬНИХ КОНКУРЕНТНИХ РИНКАХ
}

\author{
Уткіна Ю.М., к.е.н., доцент, \\ Сюсько К.Ю., махістр (УкрДУЗТ)
}

\begin{abstract}
Стрімкість розвитку глобальних конкурентних ринків зобов'язує украӥнські підприємства забезпечувати швидку адаптаиію до змін зовнішнього середовища, завойовувати й утримувати певну частку ринку, а також прагнути до ї̈ розширення. Саме тому все гостріше постає проблема забезпечення та підтримання конкурентоспроможності украйнських підприємств на глобальних конкурентних ринках. При изьому на перше місие виходить інноваиійно-інвестиційний прочес, який сприяє впровадженню передових досягнень науки та техніки та стимулюе залучення тимчасово вільних грошових коштів з метою фінансування розвитку науки. Інноваційно-інвестиційний процес являє собою процес розробки, створення та впровадження інновачійного продукту за допомогою залучення інвестииійних ресурсів. Він виступає запорукою забезпечення конкурентоспроможності продукиї̈, $a$, отже, $\check{u}$ конкурентоспроможності украӥнських підприємств на глобальних ринках, оскільки спрямований на скорочення часу виходу продукиї на ринок і витрат на виробництво та просування продукиії, а також підвищення ії якості.
\end{abstract}

Ключові слова: глобальні конкурентні ринки, конкурентоспроможність підприємств, інновацій, інвестицій, інноваційно-інвестиційний процес

\section{ИННОВАЦИОННО-ИНВЕСТИЦИОННЫЕ ПОДХОДЫ К ОБЕСПЕЧЕНИЮ КОНКУРЕНТОСПОСОБНОСТИ УКРАИНСКИХ ПРЕДПРИЯТИЙ НА ГЛОБАЛЬНЫХ КОНКУ РЕНТНЫХ РЫНКАХ}

\author{
Уткина Ю.Н., к.э.н., доцент, \\ Сюсько К.Ю., магистр (УкрГУЖТ)
}

\begin{abstract}
Стремительность развития глобальных конкурентных рынков обязывает украинские предприятия обеспечивать быструю адаптаџию к изменениям внешней среды, завоевывать и удерживать определенную долю рынка, а также стремиться к ее расширению. Именно поэтому все острее встает проблема обеспечения и поддержсания конкурентоспособности
\end{abstract}

(C) Уткіна Ю.М.,

Сюсько К.Ю.

Вісник економіки транспорту і промисловості № 52, 2015 